\title{
Heritability of Intramammary Infections at First Parturition and Relationships with Sire Transmitting Abilities for Somatic Cell Score, Udder Type Traits, Productive Life, and Protein Yield
}

\author{
D. L. Nash, ${ }^{\star, 1}$ G. W. Rogers, ${ }^{\star, 2}$ J. B. Cooper, ${ }^{, 2}$ G. L. Hargrove, ${ }^{*}$ and J. F. Keown† \\ *Department of Dairy and Animal Science, The Pennsylvania State University, University Park 16802 \\ †Department of Animal Science, University of Nebraska, Lincoln 68583
}

\begin{abstract}
The objective of this study was to determine the relationships among daughter intramammary infections at first parturition and sire transmitting abilities for somatic cell score, udder type traits, productive life, and protein yield. Quarter milk samples from 958 daughters (in eight Pennsylvania herds and one Nebraska herd) of 182 Holstein sires were collected within a few days of first calving and cultured to determine intramammary infection status. A total of 446 cows had intramammary infections in 835 quarters at first parturition. Incidence of intramammary infections at first parturition and the proportion of quarters infected per cow were regressed on age at first calving, days in milk at sample collection, herd-season of calving (a classification variable), and sire transmitting abilities taken one at a time. Linear effects, non-linear effects, and odds ratios were estimated for sire transmitting abilities. Separate, preplanned analyses were conducted on data from one herd that gave all heifers an intramammary antibiotic infusion in each quarter $30 \mathrm{~d}$ prior to the expected calving date. Separate analyses were also conducted on dependent variables that considered intramammary infections at first parturition from: all organisms, coagulasenegative staphylococci, coliform species, streptococci other than Streptococcus agalactiae, and the most common environmental organisms (coliform species and streptococci other than Streptococcus agalactiae). Daughters of sires that transmit the lowest somatic cell score had the fewest intramammary infections at first parturition. Daughters of sires that transmit longer productive life, shorter teats, and closely spaced front teats had fewer intramammary infections at first parturition. Selection for lower somatic cell score, longer pro-
\end{abstract}

Received June 7, 2002.

Accepted March 4, 2003.

Corresponding author: D. Nash; e-mail: dnash@ferrum.edu.

${ }^{1}$ Current address: Life Science Division, Ferrum College, Ferrum, VA 24088

${ }^{2}$ Current address: Department of Animal Science, University of Tennessee, Knoxville 37996 ductive life, shorter teats, or closely spaced front teats may reduce the incidence of intramammary infections at first parturition.

(Key words: intramammary infections at first parturition, somatic cell score, productive life, udder type traits)

Abbreviation key: CNS = coagulase-negative staphylococci, IIN = intramammary infection incidence, $\mathbf{P L}=$ productive life, $\mathbf{P Q I}=$ proportion of quarters infected per cow, SNA = streptococci other than Streptococcus agalactiae, STA = standardized transmitting abilities .

\section{INTRODUCTION}

Mastitis has been estimated to cost US dairy farms approximately $10 \%$ of the total value of their milk sales, or nearly $\$ 2$ billion dollars, each year (National Mastitis Council, 1996). Improvements in management have reduced mastitis from contagious organisms, especially Streptococcus agalactiae (National Mastitis Council, 1996). However, economic losses due to mastitis will continue because the dairy cow's environment contains causative organisms which cannot be eradicated (National Mastitis Council, 1996). Economic losses may even increase because the genetic correlation between mastitis and milk yield is unfavorable (Schmidt and Van Vleck, 1965; Emanuelson et al., 1988; Shook, 1989; Shook, 1993; Rogers et al., 1998). Consequently, selection for resistance to mastitis is needed to counteract the increased susceptibility to mastitis accompanying selection for milk yield. The relatively greater value of yield compared to mastitis resistance under current economic conditions dictates that yield should be emphasized much more heavily in selection programs than measures of resistance to mastitis. For example, the Net Merit index calculated by the Animal Improvement Programs Laboratory of USDA emphasizes yield approximately four times as much as measures of resistance to mastitis (VanRaden, 2000).

Records of clinical mastitis occurrence are not readily available for most US dairy cattle. As a result, other selection criteria are needed to improve resistance to 
mastitis. Selection criterion under consideration include SCS, udder type traits, and productive life (PL).

Previous research has indicated that longer PL and desirable udder conformation are associated with lower SCC and decreased clinical mastitis (Seykora and McDaniel, 1986; Rogers et al., 1991; Rogers et al., 1998). However, no study has examined the relationships between IMI at first parturition and PL or udder type traits.

Approximately 93\% of the cows in the national DHIA milk recording program, representing $46 \%$ of all US dairy cows, have milk SCC recorded monthly (Wiggans, 2002). Somatic cells in milk increase primarily due to the presence of mastitis causing organisms in the udder (Harmon, 1994). However, it has been hypothesized that high SCC indicates difficulty in preventing mastitis pathogens from entering and colonizing the udder, rather than superior immune response to invading pathogens (Coffey et al., 1986). Therefore, selection for lower SCS (a logarithmic transformation of SCC) may improve resistance to mastitis (Young et al., 1960; Coffey et al., 1986; Emanuelson et al., 1988; Shook, 1989; Philipsson et al., 1995; Rogers et al., 1998).

Data on IMI at first parturition may help clarify the relationship between mastitis and SCS. The relationship between IMI at first parturition and SCS has not been studied extensively. This relationship is of interest because heifers have yet to experience milking time exposure to mastitis causing organisms, which may confound interpretation of the relationship between mastitis measured later in life and SCS. Furthermore, unlike clinical mastitis, IMI at first parturition can be measured objectively.

If daughters of sires that transmit lower SCS have higher incidence of IMI at first parturition, then lower SCS may be an indicator of inadequate immune response to invading pathogens. However, if daughters of sires that transmit lower SCS have lower incidence of IMI at first parturition, then lower SCS may indicate the ability to either prevent mastitis pathogens from entering the udder or keep them from surviving long enough to multiply. Even if the preceding were true, it is possible that selection for lower SCS may not improve resistance to mastitis from every organism because the etiology of each mastitis-causing organism is different (National Mastitis Council, 1996; Shook, 1993). Therefore, the objectives of this study were to estimate the heritability of IMI at first parturition from the most prevalent organism groups and determine the relationships among daughter IMI at first parturition from these organisms and sire transmitting abilities for SCS, udder type traits, PL, and protein yield.

\section{MATERIALS AND METHODS}

\section{Data}

Initially, the data set included culture results for quarter samples collected near first parturition from 1051 Holstein cows in nine herds (eight in Pennsylvania and one in Nebraska). Culture results for 14 cows that had an unknown sire and 10 cows that did not have any uncontaminated quarter samples were removed from the initial data set. If zero to three organisms were detected in a quarter sample, it was classified as uncontaminated. Detection of more than three organisms in a quarter sample indicates that aseptic collection procedures were not followed. Culture results were also removed from the data set for four cows that calved before 22 mo of age and 12 cows that calved after 33 mo of age because these animals may have experienced an atypical environment. Culture results were also deleted for 53 cows that did not have quarter samples collected within $4 \mathrm{~d}$ before or after calving. Culture results from cows that had quarter samples collected more than $4 \mathrm{~d}$ after calving were not considered because of the increased chance that any organisms detected had been introduced to the udder as a result of milkingtime exposure. Culture results from cows that had quarter samples collected more than $4 \mathrm{~d}$ prior to calving were not considered due to a lack of contemporaries. The final data set (after edits) included culture results for quarter samples collected near first parturition from 958 cows. Approximately $79 \%$ of the quarter samples in the final data set were collected on the day of calving or within the first $2 \mathrm{~d}$ thereafter, and only $1 \%$ were collected before calving.

Research technicians taught herdsmen the techniques for avoiding contamination when collecting milk samples. Research technicians also made weekly visits to the Pennsylvania herds to ensure that the study protocol was being followed. Quarter samples were frozen and transported weekly to diagnostic laboratories in Pennsylvania and Nebraska for culturing following procedures described previously (Nash, 1999).

\section{Analyses}

Two dependent variables were constructed. A binary variable denoted incidence of IMI at first parturition (IIN) by assigning 0 to cows that did not have IMI and 1 to those that did. There were cows that had one to three contaminated or missing quarter samples, but did not have any bacteriologically positive and uncontaminated quarter samples. These cows were not considered to have IMI at first parturition. The proportion of quarters infected per cow at first parturition (PQI) was calculated as the number of infected quarters per 
Table 1. Possible values of the proportion of quarters infected per cow.

\begin{tabular}{lll}
\hline $\begin{array}{l}\text { Infected } \\
\text { quarters }\end{array}$ & $\begin{array}{l}\text { Uncontaminated } \\
\text { quarters }^{1}\end{array}$ & $\begin{array}{l}\text { Proportion } \\
\text { of quarters } \\
\text { infected } \\
\text { per cow }^{2}\end{array}$ \\
\hline 0 & $0,1,2,3$, or 4 & 0 \\
1 & 1 & 1 \\
1 & 2 & 0.5 \\
1 & 3 & 0.33 \\
1 & 4 & 0.25 \\
2 & 2 & 1 \\
2 & 3 & 0.67 \\
2 & 4 & 0.5 \\
3 & 3 & 1 \\
3 & 4 & 0.75 \\
4 & 4 & 1 \\
\hline
\end{tabular}

${ }^{1}$ Quarters that had uncontaminated milk samples.

${ }^{2}$ The proportion of quarters infected per cow was calculated as the number of infected quarters per cow divided by the number of uncontaminated quarters per cow.

cow divided by the number of uncontaminated quarters per cow. Possible values for PQI are in Table 1.

Both IIN and PQI were regressed on herd-season of calving (a classification variable), age at first calving, DIM at sample collection, and sire transmitting abilities for SCS, udder type traits, PL, and protein yield taken one at a time. When PQI was the dependent variable, linear and quadratic effects were estimated for each of the transmitting abilities using the GLM procedure of SAS (SAS Inst., Inc., 1995b). Cubic effects were also estimated for PTA for SCS. When IIN was the dependent variable, odds ratios were estimated for each of the transmitting abilities by using the PROBIT procedure of SAS (SAS Inst., Inc., 1995b) to perform logistic regression.

The relationships among IIN and sire transmitting abilities were investigated using logistic regression because, unlike linear regression, it is designed for analysis of data derived from a binomial distribution (Collett, 1991). In addition, the predicted values obtained through linear regression are not restricted to values between zero and one (Collett, 1991). The logistic transformation (the natural logarithm of the odds of a success) guarantees that the predicted values lie between zero and one (Collett, 1991).

Before data on IMI at first parturition were collected, it was known that all heifers in one cooperating herd received an intramammary antibiotic infusion in each quarter $30 \mathrm{~d}$ prior to the expected calving date. Therefore, separate, pre-planned analyses were conducted on data from the herd that administered an intramammary antibiotic infusion before calving. Separate analyses were also conducted on dependent variables that considered IMI at first parturition from: all organisms, coagulase-negative staphylococci (CNS), coliform species, streptococci other than Streptococcus agalactiae (SNA), and the most common environmental organisms (coliform species and SNA). Forty-six quarters were infected with two organisms. These quarters were considered to have IMI from each organism when IMI from different organism groups were analyzed separately. No quarters were infected with three organisms.

The standardized transmitting abilities (STA) for udder type traits were not available for nine sires. Consequently, data from the 10 daughters of these sires were excluded when IIN or PQI were regressed on STA for udder type traits.

Separate estimates of the heritability of IIN and PQI from each of the organism groups described above were calculated from sire variances estimated using the ASREML (Gilmour, 2001) program's implementation of the restricted maximum likelihood method. A normal linear model was assumed for PQI and a logistic model was assumed for IIN (Gilmour et al., 2001). Both models included sire, herd-season of calving, age at first calving, and DIM at sample collection. Each model was a mixed model; sire was a random effect, all other independent variables were fixed effects. Sire and herdseason of calving were classification variables. Both models considered relationships among sires. Standard errors for the heritability estimates were calculated by ASREML (Gilmour, 2001). Separate heritability estimates were calculated for data from the herd that administered an intramammary antibiotic infusion before calving. Only data from daughters of sires that had three or more progeny among the cows contributed by the cooperating herds were used to obtain heritability estimates.

\section{RESULTS AND DISCUSSION}

\section{Data}

Table 2 contains the means, standard deviations, and ranges for IIN and PQI for the organism groups and herds described above. A total of 446 of 958 cows (47\%) had IMI in 835 of 3463 uncontaminated quarters (24\%) at first parturition. The CNS were detected in 358 cows (37\%) and 606 quarters (17\%). The SNA were detected in 107 cows (11\%) and 134 quarters (4\%). Coliform species (Escherichia coli and Klebsiella species) were detected in 61 cows $(6 \%)$ and 69 quarters (2\%). Gram positive bacilli were detected in 26 cows (3\%) and 34 quarters (1\%). All other organisms were detected in 31 cows $(3 \%)$ and 36 quarters (1\%), including 14 cows (1\%) and 19 quarters $(<1 \%)$ that were infected with Staphylococcus aureus. Streptococcus agalactiae was not detected in any quarters. A total of 142 cows were infected with multiple organisms. Twenty-four quarters $(<1 \%$ 
Table 2. Incidence of intramammary infections at first parturition and the proportion of quarters infected per cow by organism group.

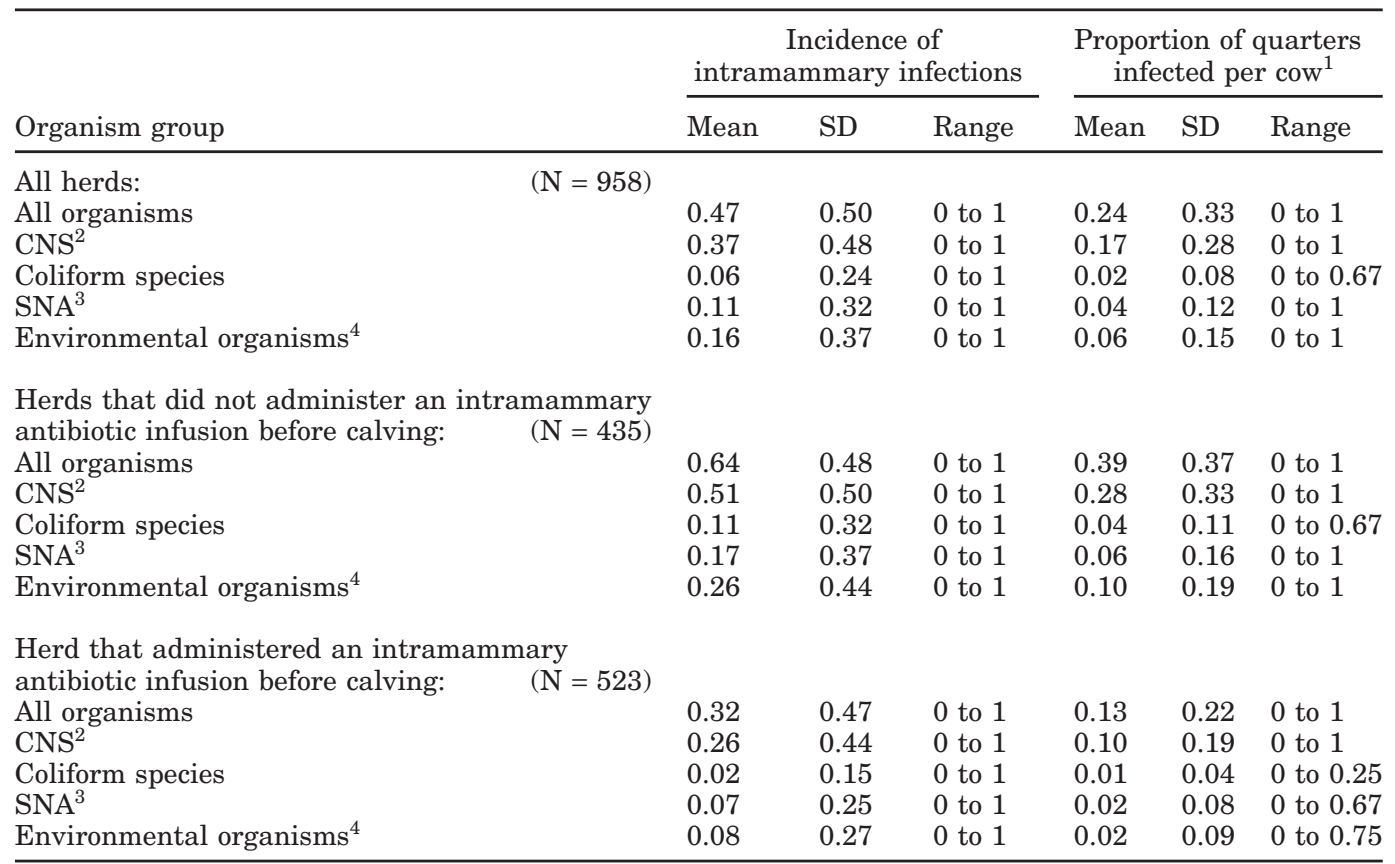

\footnotetext{
${ }^{1}$ The proportion of quarters infected per cow was calculated as the number of infected quarters per cow divided by the number of uncontaminated quarters per cow.

${ }^{2} \mathrm{CNS}=$ Coagulase-negative staphylococci.

${ }^{3} \mathrm{SNA}=$ Streptococci other than Streptococcus agalactiae.

${ }^{4}$ Coliform species and streptococci other than Streptococcus agalactiae.
}

of all quarters) were not sampled; no cows were missing milk samples for all quarters. A total of 345 quarters samples (9\% of all quarters) classified as contaminated. Of the cows that had IMI at first parturition, $49 \%$ had one infected quarter, $24 \%$ had two infected quarters, $18 \%$ had three infected quarters, and $9 \%$ had four infected quarters. Nash (1999) determined that the incidence of IMI at first parturition as well as the types and relative proportions of organisms detected in infected quarters were similar to that found in other studies.

Seven of the cooperating herds were commercial herds (all in Pennsylvania), and two were university research herds. The herds used in this study were considered to be representative of most dairy herds. All cooperating herds contained only Holstein cows. The cooperating herds contributed between 26 and 523 cows each to the study; seven of the herds contributed 71 or fewer cows. In two of the herds, the incidence of IMI at first parturition among the cows contributed to the study was $32 \%$. All heifers in one of these herds, the largest in the study (contributed 523 cows), received an intramammary antibiotic infusion in each quarter 30 $\mathrm{d}$ prior to the expected calving date. In the seven other herds, incidence of IMI at first parturition among the cows contributed to the study averaged $75 \%$ and ranged from $59 \%$ to $86 \%$.

The average age at first calving for the 958 cows was $25 \mathrm{mo}$ ( $\mathrm{SD}=2 \mathrm{mo}$ ), and the most frequently occurring age at first calving was 24 mo. Approximately $91 \%$ of the heifers calved for the first time between 23 and 27 mo of age.

Fourteen seasons of calving were defined, beginning in July, 1991 and ending in December, 1995. All seasons were 4 mo in duration (July through October, November through February, and March through June), except for the last, which ran from November through December, 1995.

The 958 cows were sired by 182 Holstein bulls. The PTA and STA from the USDA Sire Summary of November, 1997 (1997) and Holstein Association USA (1997) are summarized for these sires in Table 3. The mean number of daughters per sire was 5.3 and the mode was one daughter per sire. One bull had 156 daughters (16\% of the cows) in the cooperating herds. Another bull had 134 daughters (14\% of the cows). All other sires had no more than 56 daughters each. One hundred twenty-three sires had two or fewer daughters each. One hundred thirty-nine sires had one or more daughters that had IMI at first parturition. 
Table 3. Predicted and standardized transmitting abilities for sires of Holstein cows that had quarter samples collected to determine intramammary infection status at first parturition.

\begin{tabular}{llllcc}
\hline Transmitting abilities & $\mathrm{N}$ & Mean & SD & Minimum & Maximum \\
\hline Somatic cell score $\left(\log _{2}\right)$ & 182 & 3.21 & 0.196 & 2.76 & 3.72 \\
Protein $(\mathrm{kg})$ & 182 & 7.01 & 8.72 & -33.1 & 28.1 \\
Productive life & 182 & 0.363 & 1.25 & -3.00 & 3.60 \\
Fore udder attachment & $173^{1}$ & 0.0423 & 1.15 & -3.01 & 2.84 \\
Rear udder height & 173 & 0.274 & 1.09 & -3.52 & 2.92 \\
Rear udder width & 173 & 0.297 & 1.04 & -3.11 & 3.08 \\
Udder cleft & 173 & 0.147 & 1.18 & -3.63 & 2.59 \\
Udder depth & 173 & -0.197 & 1.44 & -4.34 & 3.42 \\
Front teat placement & 173 & 0.0775 & 1.39 & -4.26 & 3.46 \\
Teat length & 173 & 0.0469 & 1.39 & -3.83 & 4.34 \\
\hline
\end{tabular}

${ }^{1}$ The standardized transmitting abilities for udder type traits were not available for nine sires.

The two bulls with the most daughters sired approximately $30 \%$ of the daughters in the data set. However, 148 of the 156 daughters of the sire with the most daughters were owned by the herd that administered an intramammary antibiotic infusion before calving. Likewise, 127 of the 134 daughters of the sire that had the second most daughters were owned by this herd. Consequently, the effect of these bulls were limited to the analyses that included only the data from the herd that administered an intramammary antibiotic infusion before calving. The results of the analyses of the data from the herds that did not administer an intramammary antibiotic infusion before calving should not have been impacted by these two sires because the number of daughters from each was in line with the number of daughters from other sires in these herds.

\section{Heritability of IMI at First Parturition}

When data from the herd that administered an intramammary antibiotic infusion before calving were used, heritability estimates were obtained using data from 515 daughters of 17 sires. When data from the herds that did not administer an intramammary antibiotic infusion before calving were used, data from 268 daughters of 48 sires were used to obtain heritability estimates. Twenty-five sires had three to four daughters in the herds that did not administer an intramammary antibiotic infusion before calving; 16 of these 25 sires were used in only one herd, none were used in more than three herds (Figure 1). Twenty-three sires had five or more daughters in the herds that did not administer an intramammary antibiotic infusion before calving; 16 of these 23 sires were used in at least two herds, two were used in five or more herds (Figure 1).

Table 4 contains estimates of the heritability of IIN and PQI by organism group. Estimates of the heritability of IIN are adjusted to the underlying scale. The variance of a standard logistic distribution is $\pi^{2} / 3=$ 3.289 (Gilmour et al., 2001). Therefore, estimates of the heritability of IIN were adjusted to the underlying scale using the following formula: $\mathrm{h}_{\text {adjusted }}^{2}=(4 \times$ sire variance)/(sire variance + (residual variance $\times 3.289))($ Gilmour et al., 2001). Estimates of the heritability of IIN ranged from 0.00 to $>1.00$, and estimates of the heritability of PQI ranged from 0.00 to 0.48 .

Few estimates of the heritabilty of IMI exist in the literature. Detilleux et al. (1995) used data from 137 cows to estimate the heritability of IMI near first parturition to be about 0.12 . Estimates of the heritability of IMI measured throughout lactation in primiparous and multiparous cows have ranged from 0.00 to 0.20 , most estimates have been less than 0.05 (Young et al., 1960; Schmidt and Van Vleck, 1965; Weller et al., 1992).

In the current study, heritability estimates may have varied for IIN from different organism groups because the heritability of a binary trait (like IIN) is a function of its incidence (Dempster and Lerner, 1950). This characteristic of binary traits may also explain the variation in estimates of the heritability of IMI between studies.

\section{Relationships among IMI at First Parturition and Sire Transmitting Abilities}

Tables 5 and 6 contain the odds ratios, regression coefficients, and standard errors obtained when logistic

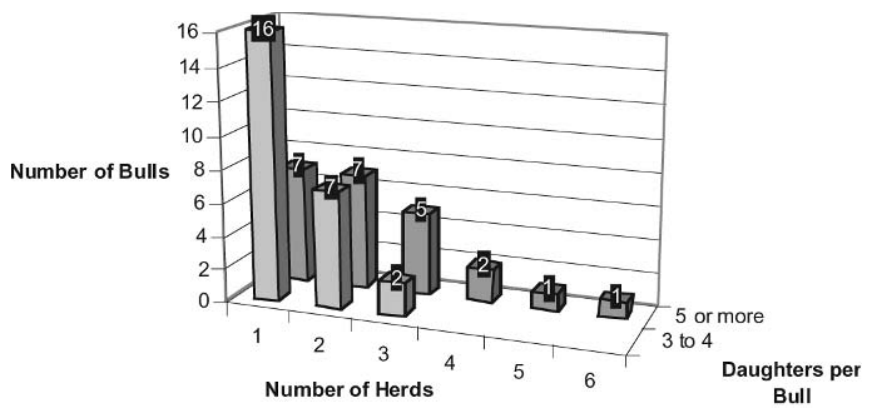

Figure 1. Distribution of the 48 sires that had at least three daughters across the herds that did not administer an intramammary antibiotic infusion before calving. 
Table 4. Heritability of the incidence of intramammary infections at first parturition and the proportion of quarters infected per cow.

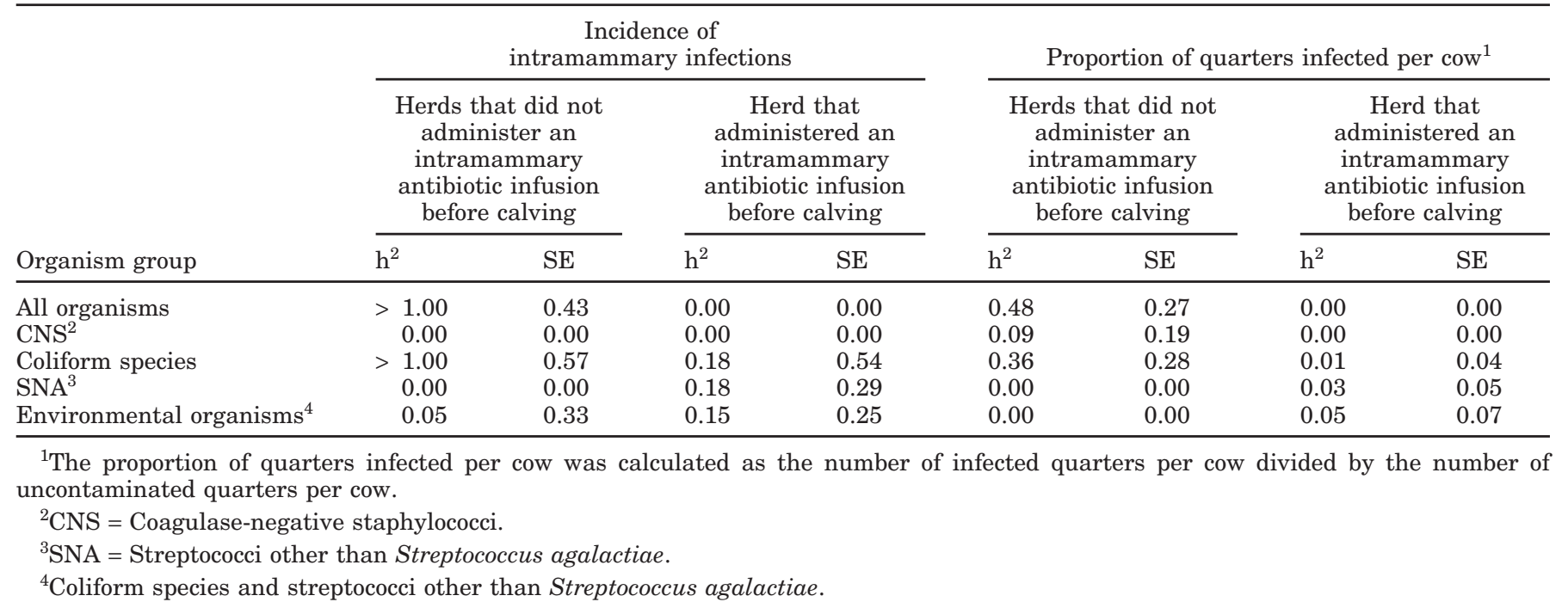

regression was used to regress IIN on PTA and STA. The regression coefficients and standard errors from regressing PQI on the linear effects of PTA and STA are in Table 7. Raw regression coefficients are reported first in each table, followed by standardized coefficients in parentheses. Odds ratios were calculated from the raw regression coefficients. Standardized regression coefficients were calculated using the following formula: standardized coefficient $=$ raw coefficient $\times\left(\mathrm{SD}_{\mathrm{x}} / \mathrm{SD}_{\mathrm{y}}\right)$ (Neter et al., 1990), where $\mathrm{SD}_{\mathrm{x}}$ is the standard deviation of each PTA or STA and $\mathrm{SD}_{\mathrm{y}}$ is the standard deviation of IIN or PQI. Standardized regression coefficients are reported, per one reviewer's suggestion, to allow readers to compare the relative importance of each trait.

Tables 5 and 7 summarize the logistic and linear regression analyses that used data from the herds that did not administer an intramammary antibiotic infusion before calving. Table 6 summarizes the logistic regression analyses that used data from the herd that administered an intramammary antibiotic infusion before calving. The linear regression analyses that used data from the herd that administered an intramammary antibiotic infusion before calving are summarized in the text. The quadratic effects of PTA and STA obtained for all data sets are summarized in the text as well.

PTA for SCS. When analyses were conducted using data from the herds that did not administer an intramammary antibiotic infusion before calving (Table 5), the PTA for SCS was a significant $(P \leq 0.05)$ predictor of IIN when all organisms, CNS, SNA, or the most common environmental organisms were considered. The odds ratios calculated from the significant logistic regression coefficients for PTA for SCS were $>1$.
The ratio of odds for a one unit change in an explanatory variable is obtained by exponentiating the regression coefficient from logistic regression (SAS Inst., Inc., 1995a). Odds ratios can be calculated only if the explanatory variable does not interact with any other variable and is represented by one term in the model (SAS Inst., Inc., 1995a). Odds ratios that are $>1(<1)$ indicate that the odds of an event increase (decrease) as the explanatory variable increases by one unit (SAS Inst., Inc., 1995a). For example, the odds ratio for PTA for SCS was 36.90 when IIN (in the herds that did not administer an intramammary antibiotic infusion before calving) from all organisms were considered (Table 5). The interpretation of this value is that the odds of a daughter having IMI at first parturition are 36.90 times higher for a one unit increase in sire PTA for SCS. Similar interpretations apply to other odds ratios in Tables 5 and 6.

If the odds ratio for a change in an independent variable of other than one unit is of interest, it can be calculated by exponentiating the product of the regression coefficient and the number of units of interest (SAS Inst., Inc., 1995a). For example, the range in PTA for SCS in this study was 0.96 (see Table 3 ) and the regression coefficient was 3.61 when IIN (in the herds that did not administer an intramammary antibiotic infusion before calving) from all organisms were considered (Table 5). Therefore, daughters of the sire that transmits the highest SCS would be $\mathrm{e}^{(0.96 \times 3.61)}=32.00$ times more likely to have IMI at first parturition than daughters of the sire that transmits the lowest SCS.

When data from the herds that did not administer an intramammary antibiotic infusion before calving were analyzed (Table 7), regressions of PQI on the linear 
Table 5. Logistic regression of daughter intramammary infection incidence at first parturition (binary variable) on sire transmitting abilities by organism group, data from the herds that did not administer an intramammary antibiotic infusion before calving.

\begin{tabular}{|c|c|c|c|c|c|c|c|c|c|}
\hline \multirow[b]{2}{*}{ Transmitting abilities } & \multicolumn{3}{|c|}{ All organisms } & \multicolumn{3}{|c|}{$\mathrm{CNS}^{1}$} & \multicolumn{3}{|c|}{ Coliform species } \\
\hline & $\mathrm{OR}^{4}$ & b-value & $\mathrm{SE}$ & OR & b-value & $\mathrm{SE}$ & OR & b-value & $\mathrm{SE}$ \\
\hline Somatic cell score & $36.90 * * *$ & $3.61(1.47)^{5}$ & $0.802^{6}$ & $9.04 * * *$ & $2.20(0.862)$ & 0.635 & 4.08 & $1.41(0.864)$ & 0.928 \\
\hline Productive life & $0.77 *$ & $-0.257(-0.685)$ & 0.107 & $0.82 *$ & $-0.204(-0.522)$ & 0.0910 & 0.95 & $-0.0554(-0.222)$ & 0.133 \\
\hline Fore udder attachment & 0.85 & $-0.158(-0.375)$ & 0.116 & 0.88 & $-0.125(-0.285)$ & 0.104 & 0.92 & $-0.0813(-0.290)$ & 0.168 \\
\hline Rear udder height & 0.94 & $-0.0651(-0.148)$ & 0.119 & 0.91 & $-0.0949(-0.207)$ & 0.106 & 1.15 & $0.137(0.467)$ & 0.167 \\
\hline Rear udder width & 0.90 & $-0.110(-0.241)$ & 0.126 & 0.92 & $-0.0814(-0.171)$ & 0.112 & 1.02 & $0.0237(0.0778)$ & 0.176 \\
\hline Front teat placement & 1.01 & $0.00773(0.023)$ & 0.0991 & 0.98 & $-0.0175(-0.0494)$ & 0.0875 & $0.72^{*}$ & $-0.335(-1.48)$ & 0.138 \\
\hline \multirow[t]{2}{*}{ Teat length } & 0.96 & $-0.0372(-0.102)$ & 0.113 & 1.00 & $0.00120(0.00317)$ & 0.0977 & 1.31 & $0.269(1.11)$ & 0.140 \\
\hline & \multicolumn{3}{|c|}{$\mathrm{SNA}^{2}$} & \multicolumn{3}{|c|}{ Environmental organisms ${ }^{3}$} & & & \\
\hline Transmitting abilities & OR & b-value & $\mathrm{SE}$ & OR & b-value & $\mathrm{SE}$ & & & \\
\hline Rear udder width & 1.06 & $0.0618(0.175)$ & 0.140 & 1.06 & $0.0579(0.138)$ & 0.125 & & & \\
\hline Udder cleft & 0.89 & $-0.116(-0.379)$ & 0.128 & 0.85 & $-0.160(-0.440)$ & 0.115 & & & \\
\hline Udder depth & 0.96 & $-0.0412(-0.160)$ & 0.105 & 0.91 & $-0.0929(-0.304)$ & 0.0922 & & & \\
\hline Front teat placement & 0.96 & $-0.0403(-0.154)$ & 0.107 & 0.86 & $-0.147(-0.471)$ & 0.0962 & & & \\
\hline Teat length & 1.09 & $0.0860(0.307)$ & 0.122 & 1.16 & $0.153(0.459)$ & 0.107 & & & \\
\hline \multicolumn{10}{|c|}{${ }^{1} \mathrm{CNS}=$ Coagulase-negative staphylococci. } \\
\hline \multicolumn{10}{|c|}{$\begin{array}{l}{ }^{2} \mathrm{CNS}=\text { Coagulase-negative staphylococcl. } \\
{ }^{2} \mathrm{SNA}=\text { Streptococci other than Streptococcus agalactiae } .\end{array}$} \\
\hline \multirow{2}{*}{\multicolumn{10}{|c|}{$\begin{array}{l}{ }^{3} \text { Coliform species and streptococci other than Streptococcus agalactiae } \\
{ }^{4} \mathrm{OR}=\text { odds ratio, b-value = regression coefficient. }\end{array}$}} \\
\hline & & & & & & & & & \\
\hline \multirow{2}{*}{\multicolumn{10}{|c|}{$\begin{array}{l}{ }^{5} \text { Raw regression coefficients reported first, followed by standardized coefficients in parentheses. Odds ratios were calculated from raw } \\
\text { regression coefficients. Standardized regression coefficients were calculated using the following formula: standardized coefficient }=\text { raw } \\
\text { coefficient } *\left(\mathrm{SD}_{\mathrm{x}} / \mathrm{SD}_{\mathrm{y}}\right) \text {, where } \mathrm{SD}_{\mathrm{x}} \text { is the standard deviation of each transmitting ability and } \mathrm{SD}_{\mathrm{y}} \text { is the standard deviation of intramammary } \\
\text { infection incidence. }\end{array}$}} \\
\hline & & & & & & & & & \\
\hline \multicolumn{2}{|c|}{$* P \leq 0.05$} & \multicolumn{8}{|c|}{${ }^{6}$ Standard errors reported for raw regression coefficients only. } \\
\hline
\end{tabular}

effect of PTA for SCS were significant $(P \leq 0.05)$ when all organisms, CNS, SNA, or the most common environmental organisms were considered. The significant regression coefficients were positive, indicating that daughters of sires that transmit higher SCS had higher PQI.

For the most part, the PTA for SCS was not a significant predictor of IIN or PQI when data from the herd that administered an intramammary antibiotic infusion before calving were analyzed. The PTA for SCS was not a significant predictor of IIN from any organism group (Table 6). Furthermore, the linear effect of PTA for SCS was a significant predictor of PQI only when the most common environmental organisms were considered (regression coefficient $=-0.0344, \mathrm{SE}=0.0160$, $P \leq 0.05$ ). The regression coefficient was negative, indicating that daughters of sires that transmit higher SCS had lower PQI when the most common environmental organisms were considered.

The preceding results may be attributed to the herd's practice of giving all heifers an intramammary antibiotic infusion in each quarter $30 \mathrm{~d}$ prior to the expected calving date. This practice has been shown to reduce incidence of IMI at first parturition (Oliver et al., 1992). In the current study, intramammary antibiotic infusion $30 \mathrm{~d}$ prior to the expected calving date may have lowered the incidence of IMI at first parturition among the daughters of the sire that had the highest PTA for SCS (3.72) and the second most daughters (134). One hundred and twenty-seven of this sire's daughters were owned by the herd that administered an intramammary antibiotic infusion before calving, only $38(30 \%)$ had IMI at first parturition though. Conversely, six of the seven daughters $(86 \%)$ of this sire that were owned by 
Table 6. Logistic regression of daughter intramammary infection incidence at first parturition (binary variable) on sire transmitting abilities by organism group, data from the herd that administered an intramammary antibiotic infusion before calving.

\begin{tabular}{|c|c|c|c|c|c|c|c|c|c|}
\hline Transmitting abilities & \multicolumn{3}{|c|}{ All organisms } & \multicolumn{3}{|c|}{$\mathrm{CNS}^{1}$} & \multicolumn{3}{|c|}{ Coliform species } \\
\hline Somatic cell score & 0.79 & $-0.239(-0.0870)^{5}$ & $0.425^{6}$ & 1.11 & $0.101(0.0393)$ & 0.448 & 0.21 & $-1.58(-1.80)$ & 1.33 \\
\hline Productive life & 0.98 & $-0.0155(-0.0253)$ & 0.0886 & 0.93 & $-0.0675(-0.118)$ & 0.0926 & 0.94 & $-0.0603(-0.309)$ & 0.251 \\
\hline Fore udder attachment & 1.05 & $0.0462(0.119)$ & 0.0909 & 1.02 & $0.0149(0.0410)$ & 0.0961 & 1.00 & $-0.000957(-0.00772)$ & 0.265 \\
\hline Rear udder height & 1.07 & $0.0682(0.149)$ & 0.134 & 1.01 & $0.00803(0.0188)$ & 0.140 & 3.52 & $1.26(8.65)$ & 0.646 \\
\hline Rear udder width & 1.05 & $0.0469(0.0960)$ & 0.128 & 1.01 & $0.0110(0.0241)$ & 0.134 & 1.31 & $0.272(1.74)$ & 0.393 \\
\hline Front teat placement & 0.95 & $-0.0517(-0.124)$ & 0.0640 & 0.97 & $-0.0331(-0.0850)$ & 0.0679 & 0.74 & $-0.303(-2.28)$ & 0.169 \\
\hline \multirow[t]{2}{*}{ Teat length } & 1.04 & $0.0405(0.182)$ & 0.0742 & 0.99 & $-0.00898(-0.0431)$ & 0.0806 & 1.33 & $0.289(4.07)$ & 0.162 \\
\hline & \multicolumn{3}{|c|}{$\mathrm{SNA}^{2}$} & \multicolumn{3}{|c|}{ Environmental organisms ${ }^{3}$} & & & \\
\hline Transmitting abilities & OR & b-value & SE & OR & b-value & $\mathrm{SE}$ & & & \\
\hline Rear udder width & 1.29 & $0.256(0.985)$ & 0.255 & 1.27 & $0.237(0.844)$ & 0.225 & & & \\
\hline Udder cleft & 0.94 & $-0.0662(-0.213)$ & 0.194 & 0.86 & $-0.149(-0.444)$ & 0.173 & & & \\
\hline Udder depth & 1.17 & $0.158(0.929)$ & 0.180 & 1.11 & $0.105(0.572)$ & 0.157 & & & \\
\hline Front teat placement & 1.01 & $0.0125(0.0565)$ & 0.115 & 0.95 & $-0.0491(-0.205)$ & 0.101 & & & \\
\hline Teat length & 1.00 & $-0.000840(-0.00709)$ & 0.129 & 1.07 & $0.0679(0.531)$ & 0.110 & & & \\
\hline
\end{tabular}

${ }^{1} \mathrm{CNS}=$ Coagulase-negative staphylococci.

${ }^{2} \mathrm{SNA}=$ Streptococci other than Streptococcus agalactiae

${ }^{3}$ Coliform species and streptococci other than Streptococcus agalactiae.

${ }^{4} \mathrm{OR}=$ odds ratio, $\mathrm{b}$-value $=$ regression coefficient .

${ }^{5}$ Raw regression coefficients reported first, followed by standardized coefficients in parentheses. Odds ratios were calculated from raw regression coefficients. Standardized regression coefficients were calculated using the following formula: standardized coefficient $=$ raw coefficient * $\left(\mathrm{SD}_{\mathrm{x}} / \mathrm{SD}_{\mathrm{y}}\right)$, where $\mathrm{SD}_{\mathrm{x}}$ is the standard deviation of each transmitting ability and $\mathrm{SD}_{\mathrm{y}}$ is the standard deviation of intramammary infection incidence.

${ }^{6}$ Standard errors reported for raw regression coefficients only.

$* P \leq 0.05$.

$* * P \leq 0.01$

$* * * P \leq 0.001$

the herds that did not administer an intramammary antibiotic infusion before calving had IMI at first parturition.

The quadratic effect of PTA for SCS (regression coefficients and standard errors not shown) was not a significant predictor of PQI from any organism group, regardless of which herds were considered. Likewise, the cubic effect of PTA for SCS (regression coefficients and standard errors not shown) was not a significant predictor of PQI from any organism group, regardless of which herds were considered.

These results do not support the theory that selection for the lowest SCS will result in dairy cattle that are unable to respond to infection. If such were the case, the lowest SCS would be associated with higher incidence of IMI at first parturition, and an intermediate SCS would provide optimal resistance to mastitis. This theory stems from the results of experimental challenge stud- ies, which indicated that elevated SCC prior to infusion protects against infection by mastitis causing organisms (Kehrli and Shuster, 1994).

Results of studies that examined the association between clinical mastitis and SCS also refute the theory that selection for the lowest SCS will result in dairy cattle that are unable to respond to infection. One study that regressed genetic evaluations for clinical mastitis on SCS evaluations detected no evidence of a non-linear effect (Philipsson et al., 1995). Another found a quadratic effect that indicated that the sires with the lowest genetic evaluations for SCS also had the most favorable evaluations for clinical mastitis (Rogers et al., 1998). Research conducted on a population which included some of the cows used in the current study concluded that daughters of sires that transmit the lowest SCS had the lowest number of clinical episodes per lactation and the least severe, shortest lasting clinical episodes 
Table 7. Linear regression of the proportion of quarters infected per cow at first parturition on sire transmitting abilities by organism group, data from the herds that did not administer an intramammary antibiotic infusion before calving. ${ }^{1}$

\begin{tabular}{|c|c|c|c|c|c|c|}
\hline \multirow[b]{2}{*}{ Transmitting abilities } & \multicolumn{2}{|c|}{ All organisms } & \multicolumn{2}{|l|}{$\mathrm{CNS}^{2}$} & \multicolumn{2}{|c|}{ Coliform species } \\
\hline & b-value ${ }^{5}$ & $\mathrm{SE}$ & b-value & $\mathrm{SE}$ & b-value & $\mathrm{SE}$ \\
\hline Somatic cell score & $0.459^{* * *}(0.243)^{6}$ & 0.0851 & $0.361 * * *(0.214)$ & 0.0788 & $0.0359(0.0640)$ & 0.0284 \\
\hline Productive life & $-0.0305^{*}(-0.106)$ & 0.0131 & $-0.0211(-0.0818)$ & 0.0120 & $-0.00102(-0.0119)$ & 0.00425 \\
\hline Fore udder attachment & $-0.0189(-0.0582)$ & 0.0147 & $-0.0170(-0.0587)$ & 0.0134 & $-0.000842(-0.00873)$ & 0.00471 \\
\hline Rear udder height & $-0.0148(-0.0436)$ & 0.0152 & $-0.0183(-0.0604)$ & 0.0139 & $0.00342(0.0339)$ & 0.00488 \\
\hline Rear udder width & $-0.0104(-0.0295)$ & 0.0163 & $-0.0121(-0.0385)$ & 0.0149 & $-0.00112(-0.0107)$ & 0.00523 \\
\hline Front teat placement & $-0.0109(-0.0415)$ & 0.0124 & $-0.00561(-0.0240)$ & 0.0114 & $-0.00875^{*}(-0.112)$ & 0.00397 \\
\hline \multirow[t]{2}{*}{ Teat length } & $-0.00264(-0.00942)$ & 0.0142 & $-0.00791(-0.0316)$ & 0.0130 & $0.0102 *(0.122)$ & 0.00453 \\
\hline & \multicolumn{2}{|l|}{$\mathrm{SNA}^{3}$} & \multicolumn{2}{|c|}{ Environmental organisms ${ }^{4}$} & & \\
\hline Transmitting abilities & b-value & $\mathrm{SE}$ & b-value & $\mathrm{SE}$ & & \\
\hline Rear udder width & $0.00201(0.0132)$ & 0.00731 & $0.00218(0.0120)$ & 0.00877 & & \\
\hline Udder cleft & $-0.00321(-0.0243)$ & 0.00660 & $-0.00914(-0.0582)$ & 0.00791 & & \\
\hline Udder depth & $-0.000370(-0.00333)$ & 0.00527 & $-0.00252(-0.0191)$ & 0.00632 & & \\
\hline Front teat placement & $0.00133(0.0117)$ & 0.00558 & $-0.00727(-0.0540)$ & 0.00669 & & \\
\hline Teat length & $-0.00126(-0.0104)$ & 0.00637 & $0.00835(0.0580)$ & 0.00763 & & \\
\hline
\end{tabular}

${ }^{1}$ The proportion of quarters infected per cow was calculated as the number of infected quarters per cow divided by the number of uncontaminated quarters per cow.

${ }^{2} \mathrm{CNS}=$ Coagulase-negative staphylococci.

${ }^{3} \mathrm{SNA}=$ Streptococci other than Streptococcus agalactiae.

${ }^{4}$ Coliform species and streptococci other than Streptococcus agalactiae.

${ }^{5} \mathrm{~b}$-value $=$ regression coefficient.

${ }^{6}$ Raw regression coefficients reported first, followed by standardized coefficients in parentheses. Standard errors reported for raw regression coefficients only. Standardized regression coefficients were calculated using the following formula: standardized coefficient $=$ raw coefficient * $\left(\mathrm{SD}_{\mathrm{x}} / \mathrm{SD}_{\mathrm{y}}\right)$, where $\mathrm{SD}_{\mathrm{x}}$ is the standard deviation of each transmitting ability and $\mathrm{SD}_{\mathrm{y}}$ is the standard deviation of the proportion of quarters infected per cow.

$* P \leq 0.05$.

$* * P \leq 0.01$.

$* * * P \leq 0.001$.

from environmental organisms during first lactation (Nash et al., 2000; Nash et al., 2002).

The findings of the current study, with regard to the association between IMI and SCS, are supported by previous research. Estimates of the genetic correlation between IMI (measured throughout lactation in primiparous and multiparous cows) and SCS averaged 0.52 and ranged from 0.24 to 0.99 (Coffey et al., 1986; Weller et al., 1992; Young et al., 1960), indicating that higher SCS is associated with more IMI. Estimates of the correlation between sire transmitting abilities for SCS and daughter IMI (measured throughout lactation) were also positive (Coffey et al., 1986).

Detilleux et al. (1995) investigated the relationship between SCS and IMI during the periparturient period. To determine IMI status during this period, duplicate samples of foremilk were collected from all quarters at calving and approximately $30 \mathrm{~d}$ before and after parturition. However, SCS was not strongly associated with IMI measured at these times. Estimates of the correlation between cows' breeding values for SCS and IMI during the periparturient period from major and minor pathogens were small ( -0.08 and 0.06 , respectively). These correlation estimates were subject to large sampling errors though because the study included only 137 cows (approximately 55\% of which were primiparous).

Because mastitis from environmental organisms is generally of shorter duration than mastitis from contagious organisms (National Mastitis Council, 1996), monthly SCC measurement (the current practice in the US) may not detect elevated SCC due to mastitis from environmental organisms. Therefore, Shook (1993) hypothesized that selection for lower SCS may not improve resistance to mastitis from environmental organ- 
isms. However, in the current study, daughters of sires that transmit higher SCS had higher IIN and PQI from all organism groups considered. These results indicate that selection for lower SCS may reduce the incidence of IMI at first parturition caused by environmental organisms or CNS. The effect of selection for lower SCS on the incidence of IMI at first parturition from other organisms (including contagious) could not be predicted because IMI caused by these organisms were not prevalent enough.

It is hypothesized that daughters of sires that transmit higher SCS had higher IIN and PQI from environmental organisms because exposure to these organisms occurs daily and the less resistant cows may become infected more often or take longer to eliminate IMI. As a result, the less resistant cows may be more likely to have elevated SCC on the day it is measured despite the relatively short duration of mastitis caused by environmental organisms.

STA for udder type traits. The linear effect of the STA for rear udder height was a significant predictor of PQI (in the herd that administered an intramammary antibiotic infusion before calving) when the most common environmental organisms were considered (regression coefficient $=0.00996, \mathrm{SE}=0.00500, P \leq 0.05$ ). The regression coefficient was positive, indicating that daughters of sires that transmitted lower rear udders had higher PQI when the most common environmental organisms were considered. Other studies have not found a consistent relationship between udder health and rear udder height. Both higher and lower rear udders have been associated with higher SCC and increased clinical mastitis (Rogers et al., 1991; Rogers et al., 1998). This indicates that associations between measures of udder health (such as PQI) and rear udder height may not have a biological basis.

Deeper udders, shallower udder cleft, and weakly attached fore udders have been associated with higher SCC and increased clinical mastitis (Seykora and McDaniel, 1986; Rogers et al., 1991; Rogers et al., 1998). However, the STA for udder depth, udder cleft, and fore udder attachment were not significant predictors of IIN or PQI from any organism group, regardless of which herds were considered.

The STA for front teat placement was a significant $(P \leq 0.05)$ predictor of IIN (in the herds that did not administer an intramammary antibiotic infusion before calving) when coliform species were considered (Table 5). Likewise, the linear effect of the STA for front teat placement was a significant predictor of PQI (in the herds that did not administer an intramammary antibiotic infusion before calving) when coliform species were considered (Table 7). The odds ratio was $<1$ and the significant regression coefficient for the linear effect was negative, indicating that daughters of sires that transmit widely spaced front teats had higher IIN and PQI when coliform species were considered. In addition, the quadratic effect of the STA for front teat placement was a significant predictor of PQI (in the herd that administered an intramammary antibiotic infusion before calving) when CNS were considered (regression coefficient $=-0.0106, \mathrm{SE}=0.00472, P \leq 0.05$ ). When plotted, the quadratic effect indicated that daughters of sires that transmit widely spaced front teats had higher PQI when CNS were considered. Widely spaced front teats have also been associated with higher SCC and increased clinical mastitis (Seykora and McDaniel, 1986; Rogers et al., 1991; Rogers et al., 1998).

The linear effect of the STA for teat length was a significant predictor of PQI (in the herds that did not administer an intramammary antibiotic infusion before calving) when coliform species were considered (Table 7). In addition, the quadratic effect of the STA for teat length was a significant predictor of PQI (in the herd that administered an intramammary antibiotic infusion before calving) when SNA or the most common environmental organisms were considered (SNA: regression coefficient $=0.00301, \mathrm{SE}=0.00148, P \leq 0.05$; environmental organisms: regression coefficient = $0.00417, \mathrm{SE}=0.00173, P \leq 0.05)$. The significant regression coefficient for the linear effect was positive, indicating that daughters of sires that transmit longer teats had higher PQI when coliform species were considered. When plotted, the quadratic effect indicated that daughters of sires that transmit longer teats had higher PQI when SNA or the most common environmental organisms were considered. Longer teats have also been associated with higher SCC and increased clinical mastitis (Seykora and McDaniel, 1986; Rogers et al., 1991; Rogers et al., 1998).

$\boldsymbol{P T A}$ for $\boldsymbol{P L}$. The PTA for PL was a significant $(P \leq$ 0.05 ) predictor of IIN (in the herds that did not administer an intramammary antibiotic infusion before calving) when all organisms or CNS were considered (Table 5). The linear effect of PTA for PL was a significant predictor of PQI (in the herds that did not administer an intramammary antibiotic infusion before calving) when all organisms were considered (Table 7). The quadratic effect of PTA for PL was not a significant predictor of PQI from any organism group, regardless of which herds were considered. The odds ratios calculated from significant logistic regression coefficients were $<1$ and the significant regression coefficient for the linear effect were negative, indicating that daughters of sires that transmit longer PL had lower IIN and PQI. Longer PL has also been associated with lower SCC and decreased clinical mastitis (Rogers et al., 1998). 
PTA for protein yield. The PTA for protein yield was not a significant predictor of IIN or PQI from any organism group, regardless of which herds were considered. However, higher yield has been associated with increased clinical mastitis and higher SCC (Emanuelson et al., 1988; Pösö and Mäntysaari, 1996; Rogers et al., 1998; Seykora and McDaniel, 1986; Weller et al., 1992).

\section{CONCLUSIONS}

Estimates of the heritability of IMI at first parturition were inconclusive. However, daughters of sires that transmit higher SCS had higher incidence of IMI at first parturition and a higher proportion of quarters infected from all organism groups considered, including IMI from all organisms. The proportion of quarters infected per cow at first parturition was linearly associated with PTA for SCS. Daughters of sires that transmit the lowest SCS had the lowest proportion of quarters infected. Therefore, selection for lower SCS may reduce the incidence of IMI at first parturition but not the ability to respond to infection. In particular, these results suggest that selection for lower SCS may reduce IMI at first parturition from environmental organisms and coagulase-negative staphylococci. The effect of selection for lower SCS on the incidence of IMI at first parturition from other organisms (including contagious) could not be predicted because IMI caused by these organisms were not prevalent in this study.

Daughters of sires that transmit longer productive life, shorter teats, and closely spaced front teats had either lower incidence of IMI at first parturition or a lower proportion of quarters infected. Therefore, selection for longer productive life, shorter teats, or closely spaced front teats may reduce the incidence of IMI at first parturition.

\section{ACKNOWLEDGMENTS}

This study was supported by a grant from the Pennsylvania Department of Agriculture. The authors thank the following cooperators for their participation: Rob Kocher of Breezy Farms (Pennsylvania Furnace, PA), Connelly brothers of Fairbrook Farms (Pennsylvania Furnace, PA), Earl Lake (Pennsylvania Furnace, PA), Ed Quigley of Luzerne Farms (Spruce Creek, PA), Doyle Waybright of Mason Dixon Farms (Gettysburg, PA), Tom Craig of Murmac Farms (Bellefonte, PA), Ray Burkholder of Statler Farms (Chambersburg, PA), Erin Marotz of the University of Nebraska-Lincoln, and Mark Amsler, Howard Wiggan, Bob Hoffman, Walker McNeill, and Myron Rudy of The Pennsylvania State University Dairy Production Research and Teaching
Center (University Park). Appreciation is expressed to the following matriculated students of The Pennsylvania State University, College of Agricultural Sciences for their assistance with data entry: Suzanne Cadwallader Beinlich, Lynette Goodling, Mark Swartz, and Derrice Ward. The authors thank Steve Galinaitis of Ferrum College for his comments and suggestions and Ryan Starkenburg of Holstein Association, USA for retrieval of data contributed by the Animal Improvement Programs Laboratory at USDA.

\section{REFERENCES}

Coffey, E. M., W. E. Vinson, and R. E. Pearson. 1986. Potential of somatic cell concentration in milk as a sire selection criterion to reduce mastitis in dairy cattle. J. Dairy Sci. 69:2163-2172.

Collett, D. 1991. Modeling binary data. 1st ed. Chapman and Hall, London, U.K.

Dempster, E. R., and I. M. Lerner. 1950. Heritability of threshold characters. Genetics 35:212-236.

Detilleux, J. C., M. E. Kehrli, Jr., A. E. Freeman, L. K. Fox, and D. H. Kelley. 1995. Mastitis of periparturient Holstein cattle: a phenotypic and genetic study. J. Dairy Sci. 78:2285-2293.

Emanuelson, U., B. Danell, and J. Philipsson. 1988. Genetic parameters for clinical mastitis, somatic cell counts, and milk production estimated by multiple-trait restricted maximum likelihood. J. Dairy Sci. 71:467-476.

Gilmour, A. R. 2001. ASREML: February 23, 2001 Version. ftp:// ftp.res.bbsrc.ac.uk/pub/aar/. Accessed July 2, 2001.

Gilmour, A. R., B. R. Cullis, S. J. Welham, and R. Thompson. 2001. ASREML Reference Manual. NSW Agriculture, Orange, Australia.

Harmon, R. J. 1994. Physiology of mastitis and factors affecting somatic cell counts. J. Dairy Sci. 77:2103-2112.

Holstein Association USA. 1997. Sire Summaries November 1997. Holstein Assoc. USA, Brattleboro, VT.

Kehrli, M. E., Jr., and D. E. Shuster. 1994. Factors affecting milk somatic cells and their role in health of the bovine mammary gland. J. Dairy Sci. 77:619-627.

Nash, D. L. 1999. Relationships among measures of daughter mastitis and sire transmitting abilities for somatic cell score, udder type traits, productive life, and yield traits. Ph.D. Diss. Pennsylvania State Univ., University Park.

Nash, D. L., G. W. Rogers, J. B. Cooper, G. L. Hargrove, J. F. Keown, and L. B. Hansen. 2000. Heritability of clinical mastitis incidence and relationships with sire transmitting abilities for somatic cell score, udder type traits, productive life, and protein yield. J. Dairy Sci. 83:2350-2360.

Nash, D. L., G. W. Rogers, J. B. Cooper, G. L. Hargrove, and J. F. Keown. 2002. Relationships among severity and duration of clinical mastitis and sire transmitting abilities for somatic cell score, udder type traits, productive life, and protein yield. J. Dairy Sci. 85:1273-1284.

National Mastitis Council. 1996. Current Concepts of Bovine Mastitis. 4th ed. Natl. Mastitis Counc., Inc., Madison, WI.

Neter, J., W. Wasserman, and M. H. Kutner. 1990. Applied Linear Statistical Models. 3rd ed. Richard D. Irwin, Inc., Boston, MA.

Oliver, S. P., M. J. Lewis, B. E. Gillespie, and H. H. Dowlen. 1992. Influence of prepartum antibiotic therapy on intramammary infections in primigravid heifers during early lactation. J. Dairy Sci. 75:406-414.

Philipsson, J., G. Ral, and B. Berglund. 1995. Somatic cell count as a selection criterion for mastitis resistance in dairy cattle. Livest. Prod. Sci. 41:195-200.

Pösö, J., and E. A. Mäntysaari. 1996. Relationships between clinical mastitis, somatic cell score, and production for the first three lactations of Finnish Ayrshire. J. Dairy Sci. 79:1284-1291. 
Rogers, G. W., G. Banos, U. Sander Nielsen, and J. Philipsson. 1998. Genetic correlations among somatic cell scores, productive life, and type traits from the United States and udder health measures from Denmark and Sweden. J. Dairy Sci. 81:1445-1453.

Rogers, G. W., G. L. Hargrove, T. J. Lawlor, and J. L. Ebersole. 1991. Correlations among linear type traits and somatic cell counts. J. Dairy Sci. 74:1087-1091.

SAS Institute, Inc. 1995a. Logistic Regression Examples Using the SAS System, Version 6 Edition. SAS Inst., Inc., Cary, NC.

SAS/STAT Software, Release 6.11. 1995b. SAS Inst., Inc., Cary, NC.

Schmidt, G. H., and L. D. Van Vleck. 1965. Heritability estimates of udder disease as measured by various tests and their relationship to each other and to milk yield, age, and milking times. J. Dairy Sci. 48:51-55.

Seykora, A. J., and B. T. McDaniel. 1986. Genetic statistics and relationships of teat and udder traits, somatic cell counts, and milk production. J. Dairy Sci. 69:2395-2407.
Shook, G. E. 1989. Selection for disease resistance. J. Dairy Sci. 72:1349-1362

Shook, G. E. 1993. Genetic improvement of mastitis through selection on somatic cell count. Vet. Clin. North Am. Food Anim. Pract. 9:563-581.

United States Department of Agriculture. 1997. November USDA Sire Summary. USDA, Washington, DC.

VanRaden, P. M. 2000. Net merit as a measure of lifetime profit. http://aipl.arsusda.gov/docs/nm2000.html. Accessed August 1, 2002.

Weller, J. I., A. Saran, and Y. Zeliger. 1992. Genetic and environmental relationships among somatic cell count, bacterial infection, and clinical mastitis. J. Dairy Sci. 75:2532-2540.

Wiggans, G. R. 2002. Dairy records processing center activity summary (DHI report K-6). http://aipl.arsusda.gov/docs/dhi/ drpc.html. Accessed August 1, 2002.

Young, C. W., J. E. Legates, and J. G. Lecce. 1960. Genetic and phenotypic relationships between clinical mastitis, laboratory criteria, and udder height. J. Dairy Sci. 43:54-62. 